Article

\title{
Knowledge Transfer Performance of Industry-University- Research Institute Collaboration in China: The Moderating Effect of Partner Difference
}

\author{
Zihanxin $\mathrm{Li}^{1 \text {,* }}$ and Guilong $\mathrm{Zhu}^{2}$ \\ 1 School of Economics and Management, Nanchang University, Nanchang 330031, China \\ 2 School of Business Administration, South China University of Technology, Guangzhou 510641, China; \\ zhug101@163.com \\ * Correspondence: lizhx@ncu.edu.cn
}

Citation: Li, Z.; Zhu, G. Knowledge Transfer Performance of Industry-

University-Research Institute

Collaboration in China: The Moderating Effect of Partner Difference. Sustainability 2021, 13, 13202. https://doi.org/10.3390/ su132313202

Academic Editor: Adriana Del Borghi

Received: 22 September 2021

Accepted: 25 November 2021

Published: 29 November 2021

Publisher's Note: MDPI stays neutral with regard to jurisdictional claims in published maps and institutional affiliations.

Copyright: (c) 2021 by the authors. Licensee MDPI, Basel, Switzerland. This article is an open access article distributed under the terms and conditions of the Creative Commons Attribution (CC BY) license (https:/ / creativecommons.org/licenses/by/ $4.0 /)$.

\begin{abstract}
How to realize the sustainable development of the industry-university-research institute (IUR) collaboration innovation ecosystem has become a key factor restricting the independent innovation capability of Chinese enterprises. Knowledge transfer performance is a key consideration in the process of R\&D collaboration between companies and research institutes; how to improve the performance of knowledge transfer depends on the matching between the partners of IUR collaboration. This article seeks to explore the influence mechanism of partner differences in the industry-university-research institute collaboration on the performance of knowledge transfer from the perspective of enterprises. Specifically, the study explores the moderating effect of technical knowledge difference and goal difference on the relationship between absorptive capacity, learning willingness, and knowledge transfer performance. The study applied the partial least squares structural equation modeling approach to model these relationships, based on survey data gathered from 211 Chinese firms. The results show that the goal difference of industry-university-research institute collaboration partners has a negative moderating effect on the relationship between learning willingness, absorptive capacity, and knowledge transfer performance. The greater the degree of goal difference, the lower the role of the enterprise's learning willingness and absorptive capacity to promote knowledge transfer performance. Technical knowledge difference has a significant inverted U-shaped effect on the relationship between absorptive capacity and knowledge transfer performance: a high degree of technical knowledge difference weakens the effects of absorptive capacity on knowledge transfer performance, while a low degree of technical knowledge difference will also negatively moderate the effects of absorptive capacity on knowledge transfer performance. The research conclusions provide scientists, government bodies, and decision makers with the necessary information for a better understanding of the effective mechanism of sustainable knowledge transfer in the IUR innovation ecosystem.
\end{abstract}

Keywords: industry-university-research institute collaboration; knowledge transfer performance; partner difference; absorptive capacity; learning willingness

\section{Introduction}

Internationalization and market competition have become increasingly fierce in recent decades, and enterprises' reliance on various forms of external collaboration has grown in an unprecedented manner [1-3]. In China, the industry-university-research institute (IUR) collaboration has achieved considerable progress under the background of the implementation of innovation strategy, and the construction of an innovative nation, from the perspective of the investment of participants and the sustainable innovation of the collaboration mode, has achieved considerable development [4]. However, the great development of IUR collaboration has not completely solved the problems of the lack of an independent innovation capability and the insufficient sustainable development of 
enterprises [5]. In 2018, domestic capital enterprises accounted for only $64.263 \%$ of the GDP of China's high tech industries; the advanced technology and new knowledge of universities and research institutes have not provided their due promotion of industrial development [6]. Some important reasons for the separation of economy and technology are that the knowledge of universities and research institutes cannot be transferred smoothly to enterprises; the enterprises cannot digest, absorb, and use new knowledge after the transfer; and the IUR collaboration fails to play its role in the acquisition of new knowledge and improvement of the independent innovation capability of enterprises $[7,8]$.

The factors that hinder the knowledge transfer performance of IUR collaboration are enterprise factors, such as learning willingness [9] and absorptive capacity [10], and university factors. Moreover, the similarity and difference between the two major participants of the collaboration also have an important influence on knowledge transfer performance [11], also determining the stability and sustainability of the industry-university-research collaboration. The difference between enterprises, universities, and research institutes is reflected mainly in the difference in knowledge and technology, and the difference in collaboration goals [12-14]. From the perspective of enterprises, the most effective way to improve the effectiveness of knowledge transfer in the short term is to choose appropriate partners according to their actual situation and strategy to match their practice, and ensure that the partner differences are within an appropriate range [15-17]. Therefore, studying the relationship between enterprises' learning willingness, absorptive capacity, partner difference, and knowledge transfer in the process of IUR collaboration, to improve the efficiency of the knowledge transfer of IUR collaboration and enhance their independent innovation capability, is of great significance.

IUR collaboration has become an important way for Chinese enterprises to improve their independent innovation capability and national sustainable innovation strategy [18]. However, how can enterprises choose IUR collaboration partners to maximize the knowledge complementarity effect? The answer is particularly urgent for Chinese enterprises, to improve their ability for independent innovation. The existing studies mainly focus on the collaboration mechanism and ignore the exploration of the partner difference and complementary choices of collaboration partners. Whether partner difference affects the knowledge transfer performance of IUR collaboration in the Chinese context, what its effects are, and how it affects knowledge transfer performance, have not been explored. Based on the practical background of IUR collaboration in China and previous studies, and with reference to the suggestions of Park [19] and Patriotta et al. [20], this paper summarizes partner difference into two dimensions: technical knowledge difference and goal difference. It overcomes difficulties such as the lack of clarity and difficulty of measuring partner difference, and lays a foundation for the construction of a theoretical model and quantitative empirical research of subsequent studies, but also for follow up research on partner difference in IUR collaboration.

In addition, in the existing studies on the factors influencing knowledge transfer performance in IUR collaboration, in addition to knowledge characteristics, knowledge source characteristics and knowledge receiver characteristics, many scholars believe that the knowledge transfer context also has an important impact on knowledge transfer performance. Most of the situational factors are from the perspective of social network theory. Trust and relationship quality are consistently recognized [21-23]. However, the partners involved in the knowledge transfer of IUR collaboration-"industry", "university" and "research institute"-have great differences, which obviously cannot be summarized through the transfer context. Based on Park [19] and Patriotta et al. [20], this study analyzes the mechanism of partner difference on the performance of knowledge transfer in detail, and enriches the academic circle's research on the factors influencing the performance of knowledge transfer. It helps enterprises to understand the differences between the partners of IUR collaboration, and then helps them to choose IUR collaboration partners according to the actual situation of enterprises, and improves the effect of IUR collaboration. 
To sum up, the existing studies on partner difference and knowledge transfer performance have mainly tested the direct impact of partner difference on innovation performance based on the theory of a resource based view and transaction costs, and lack the indirect impact of partner difference on knowledge transfer performance. For this reason, this study integrates organizational learning theory with resource based view theory and transaction cost theory, and creatively builds a theoretical framework of partner difference (technical knowledge difference, goal difference)-organizational learning ability, and willingness-knowledge transfer performance. Based on a questionnaire survey of 211 companies participating in IUR collaborations, this study uses multiple regression analysis to explore how partner difference (technical knowledge difference, goal difference) moderates the effect of learning willingness and absorptive capacity on knowledge transfer performance. The conclusions of this study are helpful to improve the intermediate mechanism of the impact of partner difference on knowledge transfer performance, and also provides a decision-making basis for enterprises to use IUR collaboration to enhance their innovation capabilities.

The remainder of the paper is organized as follows. Section 2 provides a brief theoretical background and research hypothesis derivation. Section 3 briefly describes the research methods and data sources used in this study. Section 4 presents the empirical results. Section 5 reports some conclusions and provides some theoretical and practical implications.

\section{Theoretical Background and Hypothesis Development}

\subsection{Partner Difference}

Researchers have explored and analyzed the concept from different perspectives on the influence of partner difference on interorganizational collaboration. Branzei [24] pointed out that a heterogeneous innovation network is a connection between different knowledge systems that cross organizations, institutions, and borders. Although this definition takes network heterogeneity as the target, it also explains the differences in organizational form and institutional environment among partners from a certain point of view and especially emphasizes that the root of network heterogeneity is the difference in knowledge systems.

Phelps [25] argued that partner difference in alliances originates from technological heterogeneity among alliance partners, explored the influence of alliance network structure and network components on exploratory innovation from the perspective of technological heterogeneity, and found that technological heterogeneity among alliances has a significant effect on exploratory innovation. Cui and $\mathrm{O}^{\prime}$ Connor [13] pointed out that the root cause of partner difference lies in the difference in resources, through the study of alliance combination, and emphasized that enterprises can acquire and integrate resources through learning and transfer among different partners, thereby improving the independent innovation capability of enterprises.

Similarly, Jiang et al. [12] defined partner difference as the differences between partners in resources, capabilities, knowledge structure, and technologies. To sum up, this study refers to the definition of Parkhe [26] and Lin [14], who argue that partner difference referred to the differences in organizational resources and characteristics, such as knowledge and technology capabilities, goals, etc., among multiple subjects in cooperative innovation.

For the knowledge transfer of IUR collaborations, the key problem that needs to be addressed is the obstructive effect of partner difference. We should focus not only on partner differences between the main collaboration bodies, but also on the positive and negative effects of partner differences on knowledge transfer performance. Following existing research, the dimensionality of partner difference can be summarized into the following aspects: (1) Knowledge technology differences. The main purpose of IUR collaboration is to complete the knowledge and technology transfer between universities and enterprises. Therefore, many scholars believe that the dimensions of partner difference should focus on knowledge and technology. Wuyts and Dutta [27] defined the partner technology domain from the perspective of the patent, and analyzed the technology 
differences based on this judgment. However, Satnmarra and Biggiero [28] argued that knowledge transfer between organizations in the process of collaboration should include not only technical knowledge but also market and management knowledge. Therefore, they believe that knowledge difference is embodied in three types, namely, technology, market, and management. (2) Collaboration goals differences. Organizational managers configure strategic networks according to the organization specific goals that affect innovation output. Corsaro, Cantu, and Tunisini [29] showed that the characteristics and goals of different partners will lead to different performances. Different stakeholders often have conflicting goals, strategic priorities, and needs. In an innovation network with a tendency towards collectivism, the members of the network all strive for a common network goal [30]. On the contrary, in the innovation network with a central point, the core members coordinate to ensure that the whole network achieves their own goals [31,32]. However, conflicts arise because of differences in the goals of the partners. Sometimes, such differences in goals can lead to major misunderstandings and disagreements, and strain collaboration relations, further aggravating the situation [33]. Similarities in technology domains and the compatibility of goals are considered to enhance the effectiveness of interorganizational relationships [34].

\subsection{Influence of Learning Willingness and Absorptive Capacity on Knowledge Transfer Performance}

Research on knowledge transfer performance usually synchronizes the learning willingness of the knowledge receiver with the willingness to transfer of the knowledge source, to carry out in depth research. Gupta and Govindarajan [35] pointed out that incentives at the individual level of the knowledge receiver can effectively stimulate an increase in the willingness to learn. Cummings and Teng [36] also pointed out that the lack of the learning willingness of knowledge receiver is likely to induce negative emotions in the process of introducing, digesting, and absorbing new knowledge, thereby leading to the failure of knowledge transfer. Ernst \& Kim [37] pointed out that the main cause of "non-local invention syndrome" is the lack of understanding of the external knowledge of the organization and an inherent egotism. Meanwhile, resistance to external knowledge can also lead to other phenomena that can weaken the knowledge receiver's willingness to learn.

Willingness to learn refers to the degree of the willingness of the knowledge receiver to learn knowledge from knowledge sources and internalize the learned knowledge. In the process of knowledge transfer in IUR collaborations, enterprises' strong willingness to learn is the basic condition for the efficient completion of knowledge transfer. Generally speaking, a positive relationship between learning willingness and enterprise learning autonomy exists, which also positively promotes a learning effect. Hamel [38] pointed out that a willingness to absorb and digest knowledge and technology from knowledge sources is a key factor that affects the overall learning process in organizational external learning, and enterprises with a strong learning willingness are more likely to gain competitive advantages from learning. Learning willingness is conducive to deepening enterprises ${ }^{\prime}$ understanding of the transferred knowledge, realizing the growth of their knowledge stock, and fundamentally improving their independent innovation capability [39].

In addition, an enterprise's learning willingness also determines its learning and absorption capacity to some extent, thereby influencing the absorption of transferred knowledge $[40,41]$. An enterprise's strong learning motivation also means it has a strong ability of absorption only when an enterprise has a strong willingness to learn, vigorously supports knowledge transfer behavior, and provides adequate and necessary resources, for example, funding, and related facilities, etc. Through internal training and other ways of improving staff technical ability, clearing staff obstacles in the learning process is necessary to promote the absorption of transferred knowledge. Learning willingness can also drive enterprises to adjust their existing corporate cultures and relevant incentive systems, build a good organizational atmosphere, and promote the learning of internal knowledge [42] to improve the learning and absorption capacity of enterprises for external knowledge. 
To sum up, learning willingness promotes knowledge transfer performance by adjusting the scope of knowledge transfer in IUR collaboration and the learning ability of knowledge receivers. Based on this, the following hypothesis is proposed:

Hypothesis 1 (H1). The stronger the enterprise's learning willingness, the more knowledge transfer performance in IUR collaboration, that is, learning willingness has a significant positive effect on knowledge transfer performance.

Absorptive capacity refers to the ability of an enterprise to absorb external knowledge and transform it into internal knowledge [43]. Absorptive capacity is an important factor for an organization to assimilate and internalize new knowledge. Generally speaking, absorptive capacity is closely related to the knowledge base possessed by the organization. Only an enterprise with a rich knowledge reserve can effectively evaluate new knowledge from outside, assimilate it, and apply it to practical work $[44,45]$. Therefore, the sustainability of absorptive capacity becomes the basic condition for enterprises to complete an external search.

Obviously, the higher an enterprise's knowledge stock, the stronger its ability to absorb external knowledge. Accordingly, the enterprise can better absorb and apply the acquired new knowledge into daily practice [46]. Therefore, whether an enterprise can effectively use external knowledge is closely related to its absorptive capacity. In other words, the absorptive capacity of enterprises has a positive promoting effect on knowledge transfer [47]. The so called experience or knowledge stock refers to the experience and knowledge reserve previously owned by the knowledge receiver (enterprise) that is similar to the transferred knowledge. The absorptive capacity of an enterprise is determined by the relevant experience and knowledge it possesses [9]. The richer the experience and knowledge reserve, the stronger its absorptive capacity, and the better the response to knowledge transfer [9]. Therefore, experience influences knowledge transfer performance mainly through absorptive capacity. Absorptive capacity helps promote enterprises to realize more value by acquiring external knowledge [48,49].

An enterprise's absorptive capacity is determined by its internal cognitive structure [50]. The R\&D behavior and learning of enterprises promote the accumulation of knowledge and experience and, thus, constitute their unique cognitive structure. Whether the cognitive structure is reasonable has a considerable effect on the ease with which enterprises can contact new knowledge, and also has a profound effect on the ability of enterprises to understand new knowledge and integrate it with their existing knowledge. Ahuja and Katila [50] and Tomlinson [51] pointed out that an enterprise's absorption capacity has a significant effect on its learning performance. In other words, the stronger the absorptive capacity of enterprises, the higher the level of the correct interpretation of information. In IUR collaborations, as the recipient of knowledge, the enterprise's absorption capacity can help form a richer understanding of the connotation of knowledge, thereby promoting the accumulation of knowledge stock. If the absorption capacity is insufficient, it is difficult for the enterprise to internalize the technologies of universities and research institutes into enterprise knowledge.

To sum up, absorptive capacity is conducive to improving the effectiveness of knowledge transfer. Therefore, this study puts forward the following hypothesis:

Hypothesis 2 (H2). The stronger the absorptive capacity of enterprises in IUR collaborations, the better the knowledge transfer performance, that is, absorptive capacity has a significant positive effect on knowledge transfer performance.

\subsection{Moderating Effect of Partner Difference on Interorganizational Knowledge Transfer Performance}

\subsubsection{Moderating Effect of Technical Knowledge Difference}

Scholars have pointed out that the absorptive capacity of enterprises can promote the knowledge transfer of IUR collaborations. However, some scholars have found, some- 
times, no significant positive relationship between absorptive capacity and the knowledge transfer performance of IUR collaborations [52], or, even, a decidedly opposite relationship. In other words, two different discourses on absorptive capacity and knowledge transfer performance can be observed. However, the two views are not contradictory. This study believes the main reason for this controversy is that researchers often conduct analysis based on different situations. However, the knowledge structure and knowledge depth of IUR collaborations differ in different situations, and such differences may lead to poor knowledge exchange and understanding between enterprises and their partner universities, which affect the digestion and absorption of transferred knowledge [53,54]. Hence, the relationship between absorptive capacity and knowledge transfer performance is influenced by technical knowledge differences, between enterprises and their partner universities. Similarly, differences can also be observed in academic circles in this regard. Some scholars have pointed out that, because of the technical knowledge difference between IUR collaboration partners, conflicts are likely to occur between them when transferring the knowledge that needs to be transferred, or it is difficult for enterprises to digest and absorb the knowledge after the transfer [55]. In addition, Subramaniam and Youndt [56] believed that the technical knowledge difference between partners formed complementary resources and promoted the digestion and absorption of transferred knowledge.

Technical knowledge difference refers to the difference in the knowledge and skill between the knowledge source (universities and research institutes) and the knowledge receiver (enterprises) in IUR collaboration, or the degree of dissimilarity in the knowledge reserve possessed by both partners [25]. The urgency of enterprises to carry out IUR collaboration is closely related to the technical knowledge difference. If there is knowledge and technology heterogeneity between enterprises and universities and research institutions, both are likely to take active actions to reduce the degree of difference between them, thereby generating the desire for IUR collaboration and the search for appropriate external partners to carry out knowledge transfer performance. The heterogeneity of knowledge and technology between enterprises and universities and researcher institutions makes it possible for them to attract each other. If their knowledge and technology are similar, the necessity of transfer will be lost. This phenomenon is also caused by the social division of labor and specialization. In particular, under the circumstance that the technical strength of Chinese enterprises is generally weak, enterprises urgently need the participation of universities and researcher institutions in technological R\&D activities [57]. However, not all technical knowledge differences will lead to knowledge transfer of IUR collaboration. If the degree of technical knowledge difference between enterprises and universities and research institutions is too large, knowledge transfer has difficulty attracting the participation of both partners because of the failure of communication and the consideration of transfer costs.

Transferred knowledge in IUR collaborations generally belongs to the receiver (enterprise) needs. The motivation for enterprises to participate in IUR collaborations lies in the high cost of acquiring knowledge that they do not have, or creating new knowledge with their knowledge creation ability, and, thus, they choose to exchange capital, resources, knowledge, skills, and information with university research institutions. The IUR collaboration will inevitably involve the alignment of the knowledge structure between them, and the deficiency in the enterprises' technical capabilities must be compensated by relying on the external heterogeneous skills that come from the IUR collaboration partners [58,59].

Nonaka [60] pointed out that knowledge needs to be externalized by the owner before it can be transferred to other members or organizations, and the degree of the understanding of other members or organizations of the knowledge expressed by the knowledge source will further affect the degree of the internalization of explicit knowledge. Therefore, a high similarity of knowledge and technology between enterprises, universities, and researcher institutions is conducive to the occurrence of knowledge transfer. In the knowledge transfer process of IUR collaborations, the higher the complexity of knowledge, the more necessary it is that the enterprise should have similar knowledge and technology 
to the university and research institute, to understand the transferred knowledge and better absorb the transferred knowledge. The alignment of knowledge structures is fundamentally built on the condition that knowledge and technology are similar. If an enterprise wants to receive transferred knowledge from a university and research institute, it should be able to understand the transferred knowledge and an accurate understanding of knowledge cannot be separated from similar knowledge and technology. Otherwise, knowledge transfer cannot be realized or the effect of knowledge transfer is not ideal.

Tortoriello, Reagans, and Mcevily [61] pointed out that the main reason for knowledge flow is the existence of knowledge potential differences between knowledge subjects. Knowledge generally flows from high to low levels of knowledge potential energy, and the corresponding knowledge flow also carries considerable returns [62,63]. However, a knowledge potential difference between enterprises and institutes, and knowledge transfer, can certainly be formed. Generally speaking, a certain relationship between the knowledge distance between enterprises and academic research institutions, and knowledge transfer can be observed. Scholars generally believe that the larger the knowledge distance, the more knowledge can be learned and the better the corresponding knowledge transfer effect $[19,20]$. However, the knowledge distance between enterprises and academic research institutions being too large will also lead to the unsmooth realization of knowledge transfer. It can also easily lead to the failure of knowledge transfer, if the technology of the research institutions is too advanced, because the technical personnel of the enterprises lack a similar knowledge base and cannot understand and digest the knowledge from research institutions. When the knowledge distance is too small, knowledge transfer cannot be realized because of excessive knowledge consistency. Knowledge that is too similar means there may be some competition, for self protection, universities and research institutions often set obstacles to knowledge transfer in the process of collaboration or adopt an attitude of not actively cooperating [64,65]. Meanwhile, for the recipients of knowledge, their internal R\&D personnel tend to have the subconscious mind that "the same kind is less important than the same kind" for the knowledge of researchers in the research institutions because of profound knowledge and technology in relevant fields, and they think that their knowledge and technology levels are higher than that of the research institutions, which is not conducive to the completion of knowledge transfer.

To sum up, this study puts forward the following hypotheses:

Hypothesis 3 (H3). Technical knowledge difference has a significant inverted U-shaped influence on the relationship between absorptive capacity and knowledge transfer performance. A high degree of technical knowledge difference weakens the effect of absorptive capacity on knowledge transfer performance, while s low degree of technical knowledge difference also negatively moderates the effect of absorptive capacity on knowledge transfer performance.

\subsubsection{Moderating Effect of Goal Difference}

The goal difference in IUR collaborations caused by the characteristics and social functions of the participants, such as enterprises, universities, and research institutes, has attracted widespread attention [66]. From the perspective of the enterprise, for a for profit organization, its core strategic goal is to bring a return on investment to the asset owners, which leads to important goals in the collaboration to reduce the enterprise's R\&D costs, disperse innovation risks, and promote resource sharing and ability complementarity between partners [67]. Therefore, enterprises participating in IUR collaborations hope to obtain production factors and resources that enterprises rely on for survival through collaboration and resource exchange, such as human and educational resources, technical resources, equipment resources, etc. $[17,68]$. From the perspective of dynamic capabilities, enterprises' participation in IUR collaborations is aimed at improving their technological innovation capabilities [2]. From the perspective of universities and research institutes, they, as institutions providing quasipublic goods, aim at cultivating talents, carrying out scientific research, and serving society. Their goals for IUR collaboration are mainly re- 
flected in the transfer of research results to enterprises for the realization of technology industrialization [69], as well as the extraction of scientific problems from the practice of enterprises. Therefore, the goals of universities' and research institutes' participation in IUR collaboration are reflected in raising research funds, obtaining market information, improving research efficiency, obtaining patents to increase research achievements, developing new products and establishing derivative companies, as well as increasing students' practice and employment opportunities [70]. The above analysis highlights the obvious differences in the goals between the participants of IUR.

Differences can be observed not only between enterprises, universities, and research institutes, but also in the goals of projects. Strong learning willingness is conducive to the successful completion of knowledge transfer, because learning willingness, as the embodiment of enterprises' subjective will, plays an important role in guiding their behaviors. The requirements of enterprises for technical and scientific cooperation are a dynamic process, and different demands can be found in different stages; that is, enterprises have different goals for specific IUR collaboration projects. When an enterprise enters a new field for the first time, it urgently needs complete product technology to enable it to quickly produce products that meet the market needs in this field and exchange them for greater economic benefits. With the success of entering the market, enterprises are not satisfied with the current earnings or considering a development strategy, they begin to break through the technology platform of similar products, and the goal of the IUR collaboration at this stage is focused on applied technology. Even with the continuous development of enterprises and the accumulation of their knowledge and technology, they gradually begin to invest in basic generic technology and become the technology leader in the industry. Similarly, because of the limitations of their discipline development level, R\&D ability, and knowledge structure, universities and research institutes also have different goals for IUR collaboration projects. Chen et al. [5] pointed out that low level universities have limited access to government funding. To obtain scientific research funds, they are more willing to participate in IUR collaborations and cooperate at the product and technical level. When a high degree of difference can be observed between enterprises, universities, and research institutes in the goals of the collaboration projects, the influence of enterprises learning willingness on knowledge transfer performance will be weakened because the collaboration goals between them are relatively similar, regardless of how high the learning willingness of enterprises is, which makes it difficult to complete the knowledge transfer. A high degree of difference in goals can be observed, and they have big differences in the expected results of the IUR collaboration project, which may even cause the enterprise to lose the target of learning, thereby making the enterprise's willingness to learn become a tree without roots, and knowledge transfer is even impossible without learning objects.

In addition, goal differences will also affect the relationship between absorptive capacity and knowledge transfer performance. As mentioned above, an enterprise's absorptive capacity consists of four links: knowledge acquisition, digestion, transformation, and utilization. With strong absorptive capacity, enterprises can quickly digest the knowledge transferred by universities and research institutes and create new knowledge. However, the main object of absorptive capacity is knowledge, and the cooperative goal that enterprises hope to achieve in IUR collaboration. When the collaboration goals of universities, research institutes, and enterprises in IUR collaboration projects are still quite different, the final output may differ from the original intention of enterprises. In terms of an enterprise technology existence period, growth period, maturity period, and decline, Kim [71] argued that the enterprise technology of life has an important influence on the development of the technology itself and affects the process of enterprise technology management, thereby making the enterprise with external collaborator especially in the universities and research institutes collaboration goal, present dynamic change. In the introduction stage, because of the lack of technology and knowledge base, the enterprise's collaboration goal is often dominated by technology prediction and consulting. With the smooth collaboration and improvement of their understanding of the technical field, the enterprise gradually pursues 
the optimization of the product technology and production process of the collaboration in the growth stage. During the mature stage, enterprises begin to seek product transformation and technology upgrading, and need to cooperate on the generic technology of product platform.

To sum up, this study puts forward the following hypotheses:

Hypothesis 4a (H4a). Goal difference in IUR collaboration has a negative moderating effect on the relationship between learning willingness and knowledge transfer performance. The greater the degree of goal difference, the lower the promotion effect of learning willingness on knowledge transfer performance.

Hypothesis $4 \mathbf{b} \mathbf{( H 4 b )}$. Goal difference in IUR collaboration has a negative moderating effect on the relationship between absorptive capacity and knowledge transfer performance. The greater the degree of goal difference, the lower the promotion effect of absorptive capacity on knowledge transfer performance.

The theoretical framework model is shown in Figure 1.

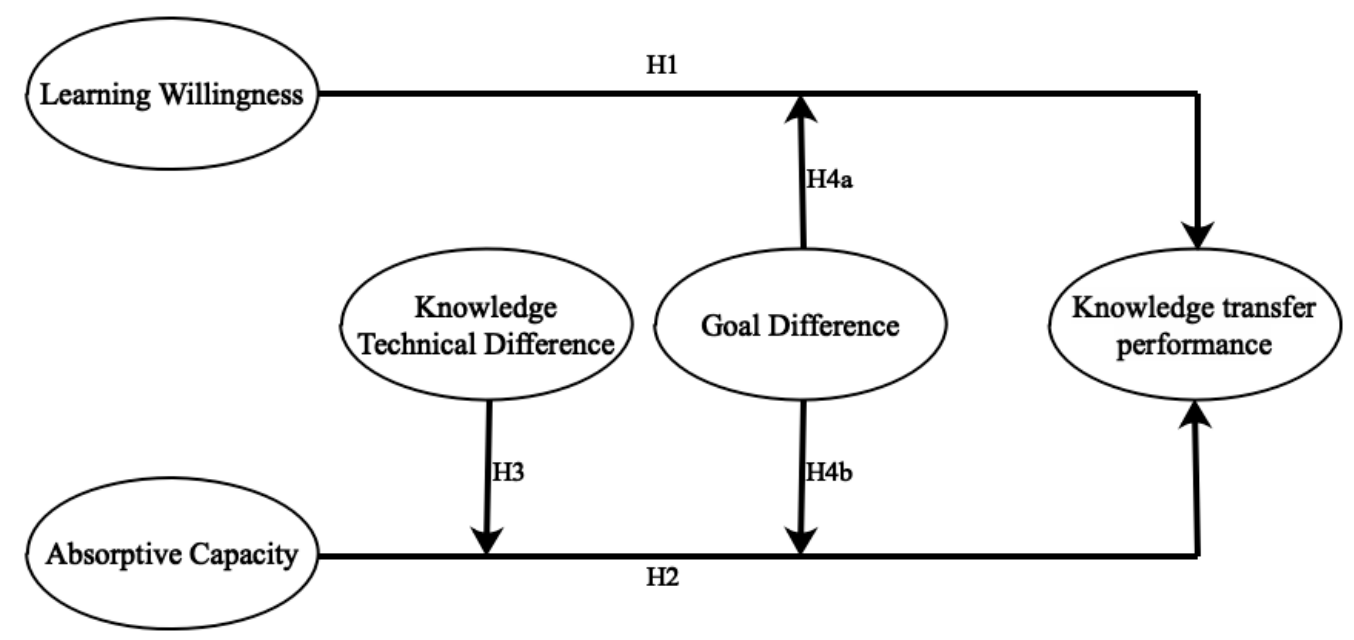

Figure 1. Theoretical framework.

\section{Data and Methods}

\subsection{Sample Selection and Data}

(1) Sample selection and sampling procedures. This paper focused on the enterprises participating in IUR collaboration based on the research objective. In order to ensure the quality of the samples, the distribution area and channels of the questionnaire were strictly restricted. In terms of the distribution area of the questionnaire, to control the regional economic development level of sample system error and consider the available social resources situation questionnaire, this study aimed at enterprises participating in IUR collaboration. The questionnaire survey was distributed to selected enterprises in Guangdong, Zhejiang, Liaoning, Jiangxi, Hu-nan and Sichuan provinces. In terms of questionnaire distribution channels, considering the reliability of sample data, this paper adopted the following distribution methods: (i) the questionnaire was sent to MBA/EMBA students from the South China University of Technology, Sun Yat-sen University, and Guangdong University of Technology on-site; (ii) distribution of the samples to relevant enterprises through relevant government cooperative institutions; (iii) relatives, classmates, and alumni were used to distribute questionnaires; and (iv) field research and interview of enterprises were conducted. As the items in the questionnaire involve the relevant situation of IUR collaboration, the respondents were required to have a relatively familiar understanding of it in the enterprises. Based on these methods, the main subjects of the questionnaire are 
the heads of technical departments and the directors of enterprises. According to the above methods and principles, a total of 836 questionnaires were issued from September 2020 to January 2021, and 307 questionnaires were finally collected, a recovery rate of $36.72 \%$. The author conducted a preliminary check on the returned questionnaires. After eliminating the questionnaires with missing or incomplete answers, and obvious regularity (highly consistent questionnaire answers), 211 questionnaires were finally determined to be valid, an overall effective recovery rate of $25.24 \%$.

(2) Sample quality control. In order to control the possible shortcomings of convenience sampling as much as possible and fully guarantee the reliability and validity of the returned questionnaires, this study carried out the following: (i) The questionnaire was conducted anonymously to avoid common method deviation. In addition, after the questionnaire was collected, single-factor analysis was used to carry out a factor analysis on all items in the questionnaire together. In this study, the first principal component interpretation rate obtained without rotation was $13.251 \%$, which did not account for the majority. Therefore, the deviation of the common method in this study was not serious. (ii) Normal distribution test was conducted on the recovered data, and the results show that the overall characteristics of the recovered data conform to the normal distribution characteristics, which can be used for subsequent analysis and research.

(3) The demographic characteristics of the sample. A brief descriptive statistical analysis was performed on the basic characteristics of the sample enterprises through the basic information items of the questionnaire samples. All the sample enterprises had carried out an IUR collaboration and had independent R\&D departments (sample enterprises without IUR collaboration experience were excluded). A total of 154 enterprises were established more than six years ago. From the perspective of firm size, 78 companies had more than 2000 employees, accounting for $36.97 \%$, and there was little difference in other levels. In terms of the nature of enterprises, private enterprises accounted for the largest proportion in the sample, reaching $62.56 \%$, a total of 132 enterprises, followed by foreign funded enterprises, joint ventures, and state-owned enterprises. In terms of industry distribution, 103 enterprises were technology intensive industries, including information technology, 72 enterprises in the traditional manufacturing industries, such as chemical industry and textile, and 21 agricultural companies. Among the 211 sample enterprises, 48 had sales revenues of over RMB 10 billion, and the rest were relatively average. In terms of R\&D capacity, 128 enterprises had more than 50 R\&D personnel, 7 enterprises had R\&D intensity of less than $1 \%$, and most enterprises had R\&D intensity between $3 \%$ and $12 \%$.

\subsection{Variable Measurement}

The measurement used in this study is based mainly on the existing research of scholars and was adjusted and revised in combination with the actual situation in China. The scale used was Likert 5-point design and self rating by the subjects. The scale was scored from 1 to 5 points, from "completely disagree" to "completely agree". To ensure the scientific and reasonable design of the questionnaire, the process of questionnaire design follows the following process: "literature review and field survey $\rightarrow$ discussion with experts in the field $\rightarrow$ discussion with government/enterprises and other management practitioners $\rightarrow$ small sample test $\rightarrow$ improvement of measurement items $\rightarrow$ finalized questionnaire". Some of the relevant scales and their measurements are described below.

Technical knowledge difference. Referencing the scale of Cummings and Teng [36], this paper uses two dimensions of knowledge technology distance and knowledge technology complementarity to measure the technical knowledge difference with a total of five items. Examples include "We can effectively absorb and digest the knowledge from the research institutions" and "We can achieve the goal of collaboration with the research institutions by complementing each other's advantages". The Cronbach's $\alpha$ value of this scale was 
0.921 , and the AVE value was 0.521 , indicating that the reliability and validity of this scale reached acceptable standards.

Goal difference. Goal difference refers to whether the collaboration goals of enterprises and research institutions are specific and clear, and whether they have the same understanding of their collaboration goals [29]. This study not only referred to the study by Simonin [40] but also combined with that of Wuyts and Dutta [27]. The scale has four items, including "There is a big difference in organizational goals between us and research institutions" and "The results of projects we cooperate with research institutions are biased towards product technology". The Cronbach's $\alpha$ value of this scale was 0.895 and the AVE value was 0.535 , indicating that the reliability and validity of the scale reached acceptable standards.

Knowledge transfer performance. Inkpen [72] pointed out that transferred knowledge is really useful and can be understood by the company, and when it is also speedy and economical, it can be called effective knowledge transfer. Pérez-Nordtvedt et al. [39] measured the effectiveness of knowledge transfer through knowledge transfer performance. Knowledge transfer performance includes four dimensions: speed, cost, effectiveness, and satisfaction. The speed dimension is formed based on Darr et al. [73] and Zander and Kogut [74], and is mainly to measure the progress of knowledge transfer between industry, university, and research institute. There are five items in total. The cost dimension measures the cost paid by enterprises in the process of knowledge transfer between industry, a university and research institute, and, mainly from the research of Hansen et al. [75], includes 5 items. The validity dimension was mainly formed based on studies by scholars such as Simonin [40] and Yli-Renko et al. [76], and consists of 5 items. The satisfaction dimension is formed by referring to the research of Szulanski [77] and combining it with the context of China. There are 3 items in total. For example, "It took us less time to complete the IUR collaboration project than previously estimated" and "After further understanding and absorption, we found that the knowledge transferred from the university research project was more useful". The Cronbach's $\alpha$ value of this scale was 0.958 , and the AVE value was 0.607 , indicating that the reliability and validity of the scale reached acceptable standards.

Learning willingness. Learning willingness refers to the willingness and motivation of enterprises to learn and absorb the knowledge and technology of research institutions, which is characterized by their subjective learning attitude and objective behaviors. This study referenced Fang et al. [78], and, through the discussion of related personnel, and drawing the learning willingness initial scale, there are 5 items, including "Learning the cooperation mechanism of knowledge and technology is one of the goals of our company's cooperation" and "Our company invested a lot of human resources and other resources to study the cooperation mechanism of knowledge and technology", etc. The Cronbach's $\alpha$ value and AVE value of this scale were 0.888 and 0.875 , indicating that the reliability and validity of the scale reached the acceptable standard.

Absorptive capacity. Absorptive capacity refers to the ability of an enterprise to acquire, digest, transform and utilize new knowledge. This study adopts the absorptive capacity scale of Szulanski [77] and fully draws on the research of Wehner et al. [79] to form the absorptive capacity scale of enterprises. There are 20 items in total. For example, "We can always solve problems quickly when we cooperate with research institutions" and "We discuss the development trend of new technology related products with research institutions", etc. The Cronbach's $\alpha$ value of this scale was 0.969 , and the AVE value was 0.593 , indicating that the reliability and validity of this scale reached the acceptable standard.

Control variables. Based on the existing research, five control variables are selected, which are industry, ownership, firm size, firm-year, and experience of IUR. The knowledge transfer of IUR is usually closely related to the industry and the nature of the firm, and the effect of knowledge transfer is also different with different industry types. The absorptive capacity of enterprise presents a positive correlation relationship between firm size, in other words, the larger the firm size, the stronger its absorptive capacity, and, in existing studies, scholars generally depict firm size through the number of employees and sales 
revenue [80], so this study draws on existing studies to represent firm size by the logarithm of the number of employees and sales revenue. In addition, the experience of IUR is also an important factor affecting knowledge transfer performance. Enterprises with rich cooperation experience can better understand the knowledge base and knowledge structure of their partners, which is conducive to better matching. Therefore, previous cooperation experience is also one of the control variables selected in this study.

\section{Results}

\subsection{Descriptive Statistics and Correlation Analysis}

Before analyzing the relationship between technical knowledge difference, goal difference, learning willingness, absorptive capacity, and knowledge transfer performance, the correlation among all variables was first analyzed, and the results are shown in Table 1. A significant positive correlation between learning willingness $(r=0.383, p<0.001)$, absorptive capacity $(r=0.369, p<0.001)$, and knowledge transfer performance can also be observed. The relationship between technical knowledge difference and knowledge transfer performance was not significant. However, a significant negative correlation between goal difference and knowledge transfer performance $(r=-0.365, p<0.05)$ was observed. Based on the above description, it can be preliminarily observed that analysis of the results of the correlation between variables show that the model and hypothesis are reasonable to a certain extent, which lays a foundation for further examination and discussion of the internal mechanism between variables.

Table 1. Descriptive statistics and correlation analysis of variables.

\begin{tabular}{cccccccc}
\hline Variable & Mean & S.D. & KTD & GOD & LEW & ASC & KTP \\
\hline KTD & 3.418 & 0.675 & $(0.921)$ & & & & \\
GOD & 3.765 & 0.468 & 0.110 & $(0.895)$ & & & \\
LEW & 4.106 & 0.517 & 0.184 & 0.137 & $(0.888)$ & & \\
ASC & 3.801 & 0.773 & 0.177 & 0.106 & 0.114 & $(0.969)$ & \\
KTP & 3.624 & 0.652 & 0.121 & $-0.365 *$ & $0.383^{* * *}$ & $0.369 * * *$ & $(0.958)$ \\
\hline
\end{tabular}

Note: $N=211 ;^{*} p<0.05,{ }^{* *} p<0.01,{ }^{* * *} p<0.001$. Data in parentheses are the coefficient of Cronbach ' $\alpha$ $\mathrm{KTD}=$ technical knowledge difference; GOD = goal difference; LEW = learning willingness; ASC = absorptive capacity; KTP = knowledge transfer performance.

\subsection{Measurement Model}

The scales used in this study were all filled out by the respondents through self statement, which may have a common method bias that reduces the study validity. According to the suggestion of Podsakoff et al. [81], the statistical test of common method bias was used to examine whether common method bias can be observed among the six variables, including self reported learning willingness, absorptive capacity, goal difference, technical knowledge difference, and knowledge transfer performance, and to investigate the discriminative validity of each variable. In addition to the baseline model with six factors, this study also used a random combination of variables to form nine alternative models. A comparison of the baseline model with the alternative model showed that the baseline model had the best fitting degree: $\chi^{2} / d f=2.281$, less than 3; TLI $=0.924, C F I=0.915$, greater than 0.9; RMSEA index is 0.056, SRMR index is 0.061, which is significantly better than the alternative model. Therefore, the six-factor baseline model can better represent the measured factor structure, indicating that the variables in this study have good discriminative validity and belong to six different constructs. The common method bias does not have a serious effect on the interpretation of the research results.

\subsection{Hypothesis Test}

In this study, multiple regression analysis was used to verify the research hypothesis. First, the control variables were incorporated into the regression model to form the initial model. Second, the independent variables were introduced into the initial model to analyze the direct effect of the independent variables on the dependent variable. Third, 
the moderating variables, independent variables, and control variables were introduced into the regression model to test the moderating effect. At the same time, to avoid the multivariable multicollinearity in the process of regression analysis, the square term and the variables in the moderating effect were centralized in this study.

We conducted a regression analysis of the moderating effect of collaboration participants' differences on the relationship between learning willingness, absorptive capacity, and knowledge transfer performance through three steps: (1) to examine the influence of control variables such as firm ownership, firm size, and R\&D intensity and industry on knowledge transfer performance; (2) to examine the influence of independent variables of learning willingness and absorptive capacity on the knowledge transfer performance of IUR collaboration; and (3) the technical knowledge difference and the goal difference of collaboration participants were introduced into the independent variable model to test their moderating effects. The specific hierarchical regression analysis results are shown in Table 2.

Table 2. Knowledge transfer performance hierarchical regression analysis results.

\begin{tabular}{|c|c|c|c|c|c|c|}
\hline & \multicolumn{6}{|c|}{ Knowledge Transfer Performance of IUR } \\
\hline & Model 1 & Model 2 & Model 3 & Model 4 & Model 5 & Model 6 \\
\hline \multicolumn{7}{|c|}{ Control variable } \\
\hline ownership & $0.132 *$ & 0.071 & 0.061 & 0.056 & 0.064 & 0.042 \\
\hline Industry & $-0.115^{*}$ & -0.094 & -0.082 & -0.080 & -0.085 & -0.098 \\
\hline firm size & 0.035 & -0.037 & -0.040 & -0.039 & -0.039 & -0.037 \\
\hline R\&D intensity & 0.039 & 0.084 & 0.098 & 0.100 & 0.094 & 0.100 \\
\hline \multicolumn{7}{|c|}{ Independent variable } \\
\hline learning willingness & & 0.374 * & $0.353 *$ & 0.336 * & $0.342 *$ & $0.324 *$ \\
\hline absorptive capacity & & $0.475^{* *}$ & $0.326^{* *}$ & $0.327^{* *}$ & $0.371^{* *}$ & 0.313 * \\
\hline technical knowledge difference & & & 0.098 & 0.119 & 0.120 & 0.113 \\
\hline technical knowledge difference ${ }^{2}$ & & & $-0.287^{* *}$ & $-0.291 * *$ & $-0.245^{* *}$ & $-0.267^{* *}$ \\
\hline goal difference & & & $-0.301 * *$ & $-0.321^{* *}$ & $-0.324^{* *}$ & $-0.340 * *$ \\
\hline \multicolumn{7}{|c|}{ Moderation } \\
\hline goal difference $\times$ learning willingness & & & & $-0.269 * * *$ & & $-0.266^{* *}$ \\
\hline $\begin{array}{l}\text { technical knowledge difference } \times \\
\text { absorptive capacity }\end{array}$ & & & & & -0.164 & -0.187 \\
\hline $\begin{array}{l}\text { technical knowledge difference } \\
\text { absorptive capacity }\end{array}$ & & & & & $-0.375^{* *}$ & $-0.328^{* *}$ \\
\hline goal difference $\times$ absorptive capacity & & & & & $-0.278 *$ & $-0.241 *$ \\
\hline $\mathbf{R}^{2}$ & 0.424 & 0.597 & 0.609 & 0.611 & 0.616 & 0.638 \\
\hline $\operatorname{Adj} R^{2}$ & 0.410 & 0.583 & 0.585 & 0.581 & 0.582 & 0.600 \\
\hline$\Delta \mathbf{R}^{2}$ & & 0.174 & 0.012 & 0.002 & 0.007 & 0.038 \\
\hline F-value & 30.136 & 43.004 & 25.711 & 20.438 & 18.234 & 16.757 \\
\hline$p$-value & 0.000 & 0.000 & 0.000 & 0.000 & 0.000 & 0.000 \\
\hline
\end{tabular}

Note: $\mathrm{N}=211 ;{ }^{*} p<0.05,{ }^{* *} p<0.01,{ }^{* * *} p<0.001$.

Table 2 shows that the F-values of the six models are all significant at the level of 0.001 , which indicates that the regression equations formed by the six models are all valid. An interpretation of the regression model shows that the $\mathrm{R}$ square of the six models was more improved than the baseline model. The $\Delta \mathrm{R}$ squares were $0.174,0.012,0.002,0.007$, and 0.027, which showed that the regression model has more explanatory power as compared with the previous baseline model in terms of the dependent variable. In addition, the variance inflation factor (VIF) of each variable ranged from 1.012 to 5.293, all lower than 10, indicating that the that multicollinearity among each variable did not exist or its influence on this study could be ignored.

Model 1 takes four control variables, namely, firm ownership, industry, firm size, and $R \& D$ intensity as independent variables to conduct regression model analysis on the knowledge transfer performance of IUR collaboration. The results show that a significant 
relationship exists between firm ownership, industry, and knowledge transfer performance of IUR. Firm ownership has a positive effect on knowledge transfer performance $(\beta=0.132$, $p<0.05)$, indicating that private firms are more inclined to knowledge transfer performance than state owned firms. A negative relationship between industry and knowledge transfer performance ( $\beta=-0.115, p<0.05)$ was also observed, that is, enterprises in the fields of information technology, telecommunications, agriculture, new energy, and new materials were more active in knowledge transfer performance than those in the traditional manufacturing industries. Firm size and R\&D intensity have no significant effect on knowledge transfer performance.

Model 2 introduced learning willingness and absorptive capacity as independent variables based on the baseline model in which the control variables were the independent variables to test hypotheses $\mathrm{H} 1$ and $\mathrm{H} 2$. The regression analysis results indicated that learning willingness had a significant positive effect on the knowledge transfer performance of IUR ( $\beta=0.374, p<0.05$ ), which indicated that the stronger learning willingness was, the more sufficient the knowledge transfer performance obtained through IUR collaboration. Hypothesis H1 was supported. Similarly, absorptive capacity also had a significant positive effect on knowledge transfer performance ( $\beta=0.475, p<0.01)$, which showed that firm absorptive capacity has a positive promoting effect on knowledge transfer performance of IUR, that is, the stronger the absorptive capacity of the firm, the more knowledge transfer performance from universities and research institutes, and, thus, Hypothesis $\mathrm{H} 2$ was supported.

In Model 3, technical knowledge difference, the square of technical knowledge difference, and goal difference were introduced into the regression model based on Model 2 to conduct a baseline model test for the subsequent moderating effect test. Table 2 shows that the goal difference $(\beta=-0.301, p<0.01)$ has a negative effect on knowledge transfer performance, and technical knowledge difference influence on knowledge transfer performance ( $\beta=0.098$, ns) was not significant, but the square of technical knowledge difference has a significant negative relation on knowledge transfer performance $(\beta=-0.287, p<0.01)$. According to the above, collaboration participants' difference has a significant effect on the knowledge transfer performance of IUR. The goal difference has a negative effect on the knowledge transfer performance, while the technical knowledge difference has an inverted U-shaped relationship with the knowledge transfer performance.

Models 4 and 5 are designed to test the moderating effect of the collaboration participants' differences in learning willingness and absorptive capacity. Both models are based on Model 3. Model 4 introduces an interaction between learning willingness and goal difference based on Model 3. At the same time, to avoid multicollinearity, the interaction and square terms in the data were centralized at the beginning of regression analysis. Then, the moderating effect of goal difference on the relationship between learning willingness and knowledge transfer performance was examined. The regression results showed that the interaction term between goal difference and learning willingness had a significant negative effect on the knowledge transfer performance $(\beta=-0.269, p<0.001)$. The above empirical analysis shows that the promotion of learning willingness on knowledge transfer performance between enterprises, universities, and research institutes will be weakened when large goal differences between enterprises, universities, and research institutes exist, while the promotion of learning willingness on collaboration will be strengthened in the case of small goal differences. Thus, Hypothesis H4a is supported.

Similar to Model 4, Model 5 further introduces the interaction between the collaboration participants' difference and absorptive capacity as independent variables for regression based on Model 3, which was used to test hypotheses H3 and H4b. As mentioned earlier, the related interaction terms were also centralized at the beginning of the process. Table 2 shows that there is no significant relationship between the interaction term of technical knowledge difference and absorptive capacity and knowledge transfer performance, while the interaction term of the square of technical knowledge difference and absorptive capacity has a significant negative effect on knowledge transfer performance $(\beta=-0.375, p<0.01)$. 
Hypothesis $\mathrm{H} 3$ is supported. The interaction between goal difference and absorptive capacity had a negative effect on knowledge transfer performance $(\beta=-0.278, p<0.05)$, Hypothesis $\mathrm{H} 4 \mathrm{~b}$ was supported. In other words, the absorptive capacity has a positive promoting effect on knowledge transfer performance, but such promoting effect is affected by the collaboration participant difference. Among them, technical knowledge difference has an inverted U-shaped influence on it, that is, when the technical knowledge difference reached a certain degree, it had the greatest influence on this kind of influence. However, goal difference had a negative weakening effect on this promoting effect.

Finally, to ensure the completeness and correctness of the moderating effect test, regression analysis of Model 6 was carried out. Based on Model 3, the interaction between learning willingness and collaboration participant difference, and the interaction between absorptive ability and collaboration participant difference were introduced simultaneously into the regression model. The empirical analysis showed that the interaction between goal difference and learning willingness $(\beta=-0.266, p<0.01)$ and the interaction between absorptive capacity $(\beta=-0.241, p<0.05)$ had significant negative effects on knowledge transfer performance in the whole model. The interaction between the square of technical knowledge difference and absorptive capacity also had a negative effect on the knowledge transfer performance $(\beta=-0.328, p<0.01)$. The above regression results are consistent with the conclusions of Models 4 and 5.

\subsection{Robustness Test}

Paired sample data were designed in this study to ensure the robustness of the results. Two interviewees were selected by the enterprise for each item to complete a set of matched data. Perez-Luno et al. [82] suggested the use of the conformance measures of the scores of different raters. The consistency coefficient $\left(R_{w g}\right)$ proposed by James et al. [83], was used to evaluate managers' consistency by calculating the consistency coefficient of sample enterprises between the two respondents. The results show that the consistency coefficient of knowledge transfer performance, learning willingness, and absorptive capacity was $0.891,0.843$, and 0.824 , respectively, and the consistency coefficient of technical knowledge difference and goal difference was 0.851 and 0.864 , respectively, which are all above the threshold of 0.6. Therefore, paired sample data are suitable for aggregating variables into population level variables for high order analysis. Based on this data, the 54 pairs of samples were averaged to test the stability of the results of this study. The regression analysis results are shown in Table 3.

Table 3. Robust analysis of knowledge transfer performance.

\begin{tabular}{|c|c|c|c|c|c|c|}
\hline & M1 $1_{\text {RT }}$ & M2 ${ }_{\mathrm{RT}}$ & M3 $3_{R T}$ & M4 $4_{\mathrm{RT}}$ & M5 & $\mathrm{M6}_{\mathrm{RT}}$ \\
\hline \multicolumn{7}{|c|}{ Control variable } \\
\hline ownership & 0.022 & 0.014 & 0.010 & 0.010 & 0.015 & 0.014 \\
\hline Industry & -0.019 & -0.015 & -0.017 & -0.114 & -0.109 & -0.025 \\
\hline firm size & 0.025 & 0.032 & 0.103 & 0.074 & 0.100 & 0.021 \\
\hline R\&D intensity & -0.045 & -0.033 & -0.051 & -0.041 & -0.042 & 0.036 \\
\hline \multicolumn{7}{|c|}{ Independent variable } \\
\hline learning willingness & & $0.353 *$ & $0.346^{*}$ & $0.340 *$ & $0.335 *$ & $0.317 *$ \\
\hline absorptive capacity & & $0.366^{* *}$ & $0.360 * *$ & $0.351^{* *}$ & $0.342^{* *}$ & $0.320 *$ \\
\hline technical knowledge difference & & & 0.009 & 0.126 & 0.138 & 0.109 \\
\hline technical knowledge difference ${ }^{2}$ & & & $-0.325^{* *}$ & $-0.321^{* *}$ & $-0.322^{* *}$ & $-0.333 * *$ \\
\hline goal difference & & & $-0.311^{* *}$ & $-0.304^{* *}$ & $-0.300^{* *}$ & $-0.267^{* *}$ \\
\hline \multicolumn{7}{|c|}{ Moderation } \\
\hline goal difference $\times$ learning willingness & & & & $-0.284^{* *}$ & & -0.261 * \\
\hline $\begin{array}{c}\text { technical knowledge difference } \times \\
\text { absorptive capacity }\end{array}$ & & & & & -0.134 & -0.120 \\
\hline
\end{tabular}


Table 3. Cont

\begin{tabular}{|c|c|c|c|c|c|c|}
\hline & $\mathrm{M1}_{\mathrm{RT}}$ & $\mathrm{M} 2_{\mathrm{RT}}$ & $\mathbf{M}_{\mathrm{RT}}$ & $\mathrm{M}_{\mathrm{RT}}$ & M5 $5_{\mathrm{RT}}$ & $\mathbf{M 6}_{\mathrm{RT}}$ \\
\hline \multicolumn{7}{|c|}{ Moderation } \\
\hline $\begin{array}{l}\text { technical knowledge difference }{ }^{2} \times \\
\text { absorptive capacity }\end{array}$ & & & & & $-0.366^{*}$ & -0.343 * \\
\hline goal difference $\times$ absorptive capacity & & & & & $-0.265^{*}$ & -0.254 * \\
\hline $\mathbf{R}^{2}$ & 0.544 & 0.603 & 0.616 & 0.631 & 0.629 & 0.663 \\
\hline Adj $R^{2}$ & 0.538 & 0.594 & 0.611 & 0.627 & 0.622 & 0.649 \\
\hline$\Delta R^{2}$ & & 0.059 & 0.013 & 0.015 & 0.013 & 0.034 \\
\hline F-value & 24.460 & 31.221 & 19.118 & 23.514 & 19.115 & 15.604 \\
\hline$p$-value & 0.000 & 0.000 & 0.000 & 0.000 & 0.000 & 0.000 \\
\hline
\end{tabular}

Note: $\mathrm{N}=66$, the coefficient after standardization; ${ }^{* * *} p<0.001 ;{ }^{* *} p<0.01 ;{ }^{*} p<0.05$.

The regression analysis results of the above robustness test showed that except for individual differences and significance level, this regression analysis had no essential difference from the regression analysis of 211 samples. The moderating effect of the collaboration participants' difference was consistent with that of the previous study, which further confirmed the reliability of the previous conclusion.

\section{Discussion, Implications, and Limitations}

This paper focuses on the effects of the collaboration participants' difference in IUR on knowledge transfer performance and explores how the collaboration participants' difference affects knowledge transfer performance and its path. Results show that goal difference negatively moderates the effects of learning willingness and absorptive capacity on knowledge transfer performance, and that technical knowledge difference has a significant inverted U-shaped influence on the relationship between absorptive capacity and knowledge transfer performance. A high degree of technical knowledge difference weakens the influence of absorptive capacity on knowledge transfer performance, while a low degree of technical knowledge difference also negatively moderates the influence of absorptive capacity on knowledge transfer performance.

\subsection{Theoretical Implications}

The results of this study have the following theoretical implications. First, the technical knowledge difference of collaboration participants has a significant inverted U-shaped moderating effect on the relationship between absorptive capacity and knowledge transfer performance. As Chen et al. [5] pointed out, if the technical knowledge difference among the partner difference of IUR collaborations is too large, even if the enterprises have strong absorption capacity, they will eventually be unable to digest and use the valuable knowledge from the other side effectively because of the huge knowledge gap, leading to a poor knowledge transfer effect $[84,85]$. Similarly, if the technical knowledge differences are too small, this indicates that the knowledge depth and knowledge structure of universities and research institutes lack complementarity for enterprises [86,87]. Even if the enterprises have a strong absorption capacity, the absorbed knowledge will have little value to the enterprise, and the knowledge transfer effect will be poor $[88,89]$. The effect of the absorptive capacity on knowledge transfer depends on the technical knowledge difference between the two collaboration participants [64,65]. Although no specific discussion on the mechanism of effects of technical knowledge difference on knowledge transfer performance can be found in the literature [90-93], the conclusion of this study can be regarded as an extension of similar studies.

Second, the goal difference of collaboration participants has a significant moderating effect on the relationship between learning willingness, absorptive capacity, and knowledge transfer performance. Cooperative theory points out that differences must exist between different participants, and the basis of collaboration is the common goal [51,94]. Relevant studies on enterprise technology alliance collaboration have pointed out that only with 
common collaboration goals can both parties invest resources actively and make joint efforts to achieve collaboration goals $[95,96]$. Similarly, as the collaboration between organizations with different attributes, IUR has huge differences in organizational goals between the participants, and such differences have been referred to as the possibility of resource complementarity between them $[97,98]$. Enterprises reduce R\&D costs and improve R\&D efficiency and their technology system through IUR, while universities and research institutes also obtain benefits from the productization and marketization of technologies through IUR, train scientific research personnel, and refine scientific problems in practice. In other words, a basis for collaboration between enterprises, universities, and research institutes exists, but there may be differences between them in terms of specific collaboration goals, and such differences have an important influence on the effect of knowledge transfer performance $[99,100]$. Enterprises at different stages have different demand types (including product technology, applied generic technology, and basic generic technology) for collaborative R\&D. In other words, differences in the types of technologies to be solved in R\&D collaboration can be observed, and the degree of such differences in goals will have a negative effect on the effect of knowledge transfer by affecting the learning willingness and absorptive capacity of enterprises.

\subsection{Practical Implications}

The 13th Five-Year Plan of China places an emphasis on the concepts of innovation, coordination, green, opening, and sharing. IUR collaboration innovation has become an important method for improving the independent innovation capability of Chinese enterprises, and is also the main starting point in the promotion of the transformation of Chinese industry from manufacturing to innovation. The key to achieving the above goals lies in how the accurate and smooth flow of knowledge from universities and research institutes to enterprises can be promoted. On the one hand, the government must carry on scientific research system reform and promote universities and research institutes for the implementation of the service function of the social economy. On the other hand, as an important subject of the economic system, enterprises need to improve their technology system, improve their independent innovation capability, and realize the sustainable growth of core competitiveness through "self-cultivation" with the help of IUR. How can enterprises choose the right IUR partners to achieve the purpose of technological breakthrough in a better and more rapid way? This study on the influence mechanism of the difference between collaboration participants on knowledge transfer performance in this paper provides the following enlightenment for the above problems of enterprise management practice.

First, learning willingness and absorptive capacity can directly promote knowledge transfer in IUR collaboration. These results indicate that the enterprise that needs to promote knowledge transfer effect first needs to promote internal absorptive capacity and knowledge absorptive capacity, which includes, mainly, the ability to knowledge recognition, digestion, and utilization, focus on the construction of internal R\&D capacity, improve the structure of the R\&D team by introducing talents, and lay a solid foundation for the absorption capacity of enterprises. If enterprises lack a strong learning willingness and good absorptive capacity, they will have no intention and no ability to acquire knowledge from universities and research institutes, and the knowledge transfer in IUR collaboration will become a fool's paradise. Chinese enterprises choose to cooperate with universities for short term interests, and lack the long term goal of improving their independent innovation capability through IUR collaboration, fundamentally leading to the poor effect of the knowledge transfer performance. Enterprises should internalize the knowledge of universities and research institutes into their knowledge reserve and prepare sufficient redundant resources for knowledge transfer from a long term strategic goal. However, learning willingness alone is not sufficient for enterprises. If they lack sufficient absorptive capacity, they may be willing, but lack the power in the face of knowledge from scientific research institutions. Therefore, enterprises should build and cultivate their internal absorp- 
tive capacity before carrying out IUR collaboration, for example, increase R\&D investment; improve R\&D systems, institutions and technical personnel training mechanisms; and introduce excellent external talents.

Second, to re-understand the difference in the collaboration participants and focus on the important influence on knowledge transfer performance of IUR. The IUR collaboration of China has had certain achievements and a number of failure cases, enterprises lack technical or unable to break through technical bottlenecks, need to seek the help of universities and research institutes. However, most enterprises ignore the difference between them and their partners. Due to the significant influence of the differences of the collaboration participants in knowledge transfer, ignoring the differences of the collaboration participants can ultimately reduce the collaboration between the two participants to a low probability event. Enterprises can realize the desire for technological breakthrough through the IUR under the normal coincidence of the differences between the collaboration participants.

Finally, in the selection of IUR collaboration partners, we should adhere to the actual situation of the enterprise itself as the basis, and not blindly choose high level research universities. The realization of IUR knowledge transfer performance depends on the enterprise's strong learning willingness and its absorptive capacity, but these are only the necessary conditions for knowledge transfer performance. We need to solve the problem from the source and find partners that match with the development of the enterprise and its technical strength, to improve the efficiency of the knowledge transfer of IUR collaboration. That is, we should choose the universities with strong complementary effects in knowledge depth and knowledge structure. However, universities with little difference in collaboration goals and concepts are not cooperating blindly with the universities with strong research comprehensive strength, because this type of university has a large depth of knowledge, and their knowledge structure and system are relatively complete. Most of these cooperation efforts focus on basic and applied generic technology and, thus, have higher requirements on the absorptive capacity of enterprises.

\subsection{Limitations and Future Research Directions}

This study is based on the shortcomings in independent innovation capability of Chinese enterprises who face the issue of knowledge transfer in IUR collaboration. Through the research on the influence mechanism of the difference of collaboration participants on knowledge transfer performance, some meaningful conclusions are obtained. These conclusions have certain theoretical value and practical significance. However, this paper has some limitations because of the limitations of time, manpower, financial resources, and research ability. First, in the measurement of variables, although the difference of the collaboration participants has gradually attracted scholars' attention, a lack of mature and available scales still persists. Therefore, this study refers to the views of a significant amount of literature and makes some deletions and additions to the variable measurement items. Although a small sample pretest and a large sample test were used in the reliability and validity analyses, the performance is good. Thus, follow up research should be combined with case interviews to readjust the scale in the Chinese context. Second, some limitations can also been seen in the sample collection. The questionnaires were distributed in Guangdong, Zhejiang, Liaoning, Jiangxi, Hunan, and Sichuan provinces, and only 211 valid questionnaires were collected, which clearly indicates a lack of representation for the entire Chinese situation. Follow up research should continue to expand the scope and scale of the questionnaire, and conduct horizontal analysis and comparison between different regions, industries, and ownership of enterprises, to obtain more universal research results. Finally, the organization of UIR in this research only includes the enterprise as the main subject. In reality, however, the UIR is composed of two participants, including enterprises and research institutions, and involves more complex problems of willingness, ability, differences of cooperation subjects, and knowledge transfer performance. Future research can be based on the industry-university research cooperation of the two main 
subjects as the research object, and further explore the relationship between the willingness, ability, and cooperation.

Author Contributions: Conceptualization, Z.L. and G.Z.; methodology Z.L.; data curation, G.Z.; writing, Z.L. and G.Z.; supervision, Z.L. All authors have read and agreed to the published version of the manuscript.

Funding: This research was funded by the National Natural Science Foundation of China (71904074, U1901222).

Institutional Review Board Statement: Not applicable.

Informed Consent Statement: Not applicable.

Data Availability Statement: The data presented in this study are available on request from the corresponding author.

Conflicts of Interest: The authors declare no conflict of interest.

\section{References}

1. Teece, D.J. Explicating dynamic capabilities: The nature and microfoundations of (sustainable) enterprise performance. Strateg. Manag. J. 2007, 28, 1319-1350. [CrossRef]

2. Tiwana, A. Does technological modularity substitute for control? A study of alliance performance in software outsourcing. Strateg. Manag. J. 2008, 29, 769-780. [CrossRef]

3. Wen, H.; Xu, Y.; Zou, K. Impact of industry association on the innovation of small and micro enterprises. Appl. Econ. Lett. 2020, 28, 1-5. [CrossRef]

4. Chen, Y.; $\mathrm{Xu}, \mathrm{Y}$; Z Zhai, Q. The knowledge management functions of corporate university and their evolution: Case studies of two Chinese corporate universities. J. Knowl. Manag. 2019, 23, 2086-2112. [CrossRef]

5. Chen, K.; Zhang, Y.; Zhu, G.; Mu, R. Do research institutes benefit from their network positions in research collaboration networks with industries or/and universities? Technovation 2020, 94-95, 102002. [CrossRef]

6. CSY. China Statistics Yearbook on High Technology Industry; China Statistical Publishing House: Beijing, China, 2019.

7. Meseguer-Sánchez, V.; Gálvez-Sánchez, F.J.; López-Martínez, G.; Molina-Moreno, V. Corporate Social Responsibility and Sustainability. A Bibliometric Analysis of Their Interrelations. Sustainability 2021, 13, 1636. [CrossRef]

8. Hong, W.; Su, Y.-S. The effect of institutional proximity in non-local university-industry collaborations: An analysis based on Chinese patent data. Res. Policy 2013, 42, 454-464. [CrossRef]

9. Cohen, W.M.; Levinthal, D. Innovation and Learning: The Two Faces of R \& D. Econ. J. 1989, 99, 569. [CrossRef]

10. Jansen, J.J.P.; Bosch, F.A.J.V.D.; Volberda, H. Managing Potential and Realized Absorptive Capacity: How do Organizational Antecedents Matter? Acad. Manag. J. 2005, 48, 999-1015. [CrossRef]

11. Cyert, R.M.; Goodman, P.S. Creating effective University-industry alliances: An organizational learning perspective. Organ. Dyn. 1997, 25, 45-57. [CrossRef]

12. Jiang, R.J.; Tao, Q.T.; Santoro, M.D. Alliance portfolio diversity and firm performance. Strateg. Manag. J. 2010, 31, 1136-1144. [CrossRef]

13. Cui, A.S.; O'Connor, G. Alliance Portfolio Resource Diversity and Firm Innovation. J. Mark. 2012, 76, 24-43. [CrossRef]

14. Lin, H. Cross-sector Alliances for Corporate Social Responsibility Partner Heterogeneity Moderates Environmental Strategy Outcomes. J. Bus. Ethics 2012, 110, 219-229. [CrossRef]

15. George, G.; Zahra, S.A.; Wood, D. The effects of business-university alliances on innovative output and financial performance: A study of publicly traded biotechnology companies. J. Bus. Ventur. 2002, 17, 577-609. [CrossRef]

16. Welsh, R.; Glenna, L.; Lacy, W.; Biscotti, D. Close enough but not too far: Assessing the effects of university-industry research relationships and the rise of academic capitalism. Res. Policy 2008, 37, 1854-1864. [CrossRef]

17. Eom, B.-Y.; Lee, K. Determinants of industry-academy linkages and, their impact on firm performance: The case of Korea as a latecomer in knowledge industrialization. Res. Policy 2010, 39, 625-639. [CrossRef]

18. Zhang, Y.; Chen, K.; Fu, X. Scientific effects of Triple Helix interactions among research institutes, industries and universities. Technovation 2019, 86-87, 33-47. [CrossRef]

19. Park, B.I. Knowledge transfer capacity of multinational enterprises and technology acquisition in international joint ventures. Int. Bus. Rev. 2011, 20, 75-87. [CrossRef]

20. Patriotta, G.; Castellano, A.; Wright, M. Coordinating knowledge transfer: Global managers as higher-level intermediaries. J. World Bus. 2013, 48, 515-526. [CrossRef]

21. Becerra, M.; Lunnan, R.; Huemer, L. Trustworthiness, Risk, and the Transfer of Tacit and Explicit Knowledge Between Alliance Partners. J. Manag. Stud. 2008, 45, 691-713. [CrossRef]

22. Easterby-Smith, M.; Lyles, M.A.; Tsang, E.W.K. Inter-Organizational Knowledge Transfer: Current Themes and Future Prospects. J. Manag. Stud. 2008, 45, 677-690. [CrossRef] 
23. Sun, C.-C. Evaluating the Intertwined Relationships of the Drivers for University Technology Transfer. Appl. Sci. 2021, 11, 9668. [CrossRef]

24. Branzei, O. Product Innovation in Heterogeneous R\&D Networks Pathways to Exploration and Exploitation. Ph.D. Thesis, The University of British Columbia, Vancouver, BC, Canada, 2004.

25. Phelps, C. A Longitudinal Study of the Influence of Alliance Network Structure and Composition on Firm Exploratory Innovation. Acad. Manag. J. 2010, 53, 890-913. [CrossRef]

26. Parkhe, A. Interfirm Diversity, Organizational Learning, and Longevity in Global Strategic Alliances. J. Int. Bus. Stud. 1991, 22, 579-601. [CrossRef]

27. Wuyts, S.; Dutta, S. Benefiting From Alliance Portfolio Diversity: The role of past internal knowledge creation strategy. J. Manag. 2014, 40, 1653-1674. [CrossRef]

28. Sammarra, A.; Biggiero, L. Heterogeneity and Specificity of Inter-Firm Knowledge Flows in Innovation Networks. J. Manag. Stud. 2008, 45, 800-829. [CrossRef]

29. Corsaro, D.; Cantù, C.; Tunisini, A. Actors' Heterogeneity in Innovation Networks. Ind. Mark. Manag. 2012, 41, 780-789. [CrossRef]

30. Perks, H.; Jeffery, R. Global network configuration for innovation: A study of international fibre innovation. RED Manag. 2006, 36, 67-83. [CrossRef]

31. Dhanaraj, C.; Parkhe, A. Orchestrating Innovation Networks. Acad. Manag. Rev. 2006, 31, 659-669. [CrossRef]

32. Klerkx, L.; Aarts, N. The interaction of multiple champions in orchestrating innovation networks: Conflicts and complementarities. Technovation 2013, 33, 193-210. [CrossRef]

33. Baraldi, E.; Strömsten, T. Controlling and combining resources in networks-From Uppsala to Stanford, and back again: The case of a biotech innovation. Ind. Mark. Manag. 2009, 38, 541-552. [CrossRef]

34. Ruekert, R.W.; Walker, O.C., Jr. Interactions between marketing and R\&D departments in implementing different business strategies. Strateg. Manag. J. 1987, 8, 233-248. [CrossRef]

35. Gupta, A.K.; Govindarajan, V. Knowledge flows within multinational corporations. Strateg. Manag. J. 2000, 21, 473-496. [CrossRef]

36. Cummings, J.L.; Teng, B.-S. Transferring R\&D knowledge: The key factors affecting knowledge transfer success. J. Eng. Technol. Manag. 2003, 20, 39-68. [CrossRef]

37. Ernst, D.; Kim, L. Global production networks, knowledge diffusion, and local capability formation. Res. Policy 2002, 31, 1417-1429. [CrossRef]

38. Hamel, G. Competition for competence and interpartner learning within international strategic alliances. Strateg. Manag. J. 1991, 12, 83-103. [CrossRef]

39. Pérez-Nordtvedt, L.; Kedia, B.L.; Datta, D.K.; Rasheed, A.A. Effectiveness and Efficiency of Cross-Border Knowledge Transfer: An Empirical Examination. J. Manag. Stud. 2008, 45, 714-744. [CrossRef]

40. Simonin, B.L. An empirical investigation of the process of knowledge transfer in international strategic alliances. J. Int. Bus. Stud. 2004, 35, 407-427. [CrossRef]

41. Escribano, A.; Fosfuri, A.; Tribo, J.A. Managing external knowledge flows: The moderating role of absorptive capacity. Res. Policy 2009, 38, 96-105. [CrossRef]

42. Frankort, H.T. When does knowledge acquisition in R\&D alliances increase new product development? The moderating roles of technological relatedness and product-market competition. Res. Policy 2016, 45, 291-302. [CrossRef]

43. Cohen, W. Absorptive Capacity: A New Perspective on Learning and Innovation. Strateg. Learn. Knowl. Econ. 2000, 35, 39-67. [CrossRef]

44. Díaz-Díaz, N.L.; Aguiar-Díaz, I.; De Saá-Pérez, P. The effect of technological knowledge assets on performance: The innovative choice in Spanish firms. Res. Policy 2008, 37, 1515-1529. [CrossRef]

45. Al-Laham, A.; Tzabbar, D.; Amburgey, T.L. The dynamics of knowledge stocks and knowledge flows: Innovation consequences of recruitment and collaboration in biotech. Ind. Corp. Chang. 2011, 20, 555-583. [CrossRef]

46. Ali, M.; Park, K. The mediating role of an innovative culture in the relationship between absorptive capacity and technical and non-technical innovation. J. Bus. Res. 2016, 69, 1669-1675. [CrossRef]

47. Weidenfeld, A.; Williams, A.M.; Butler, R.W. Knowledge transfer and innovation among attractions. Ann. Tour. Res. 2010, 37, 604-626. [CrossRef]

48. Gao, S.; Xu, K.; Yang, J. Managerial ties, absorptive capacity, and innovation. Asia Pac. J. Manag. 2008, 25, 395-412. [CrossRef]

49. Todorova, G.; Durisin, B. Absorptive capacity: Valuing a reconceptualization. Acad. Manag. Rev. 2007, 32, 774-786. [CrossRef]

50. Ahuja, G.; Katila, R. Technological acquisitions and the innovation performance of acquiring firms: A longitudinal study. Strateg. Manag. J. 2001, 22, 197-220. [CrossRef]

51. Tomlinson, P.R. Co-operative ties and innovation: Some new evidence for UK manufacturing. Res. Policy 2010, 39, 762-775. [CrossRef]

52. Rathi, D.; Given, L.M.; Forcier, E. Interorganisational partnerships and knowledge sharing: The perspective of non-profit organisations (NPOs). J. Knowl. Manag. 2014, 18, 867-885. [CrossRef]

53. Rodan, S.; Galunic, C. More than network structure: How knowledge heterogeneity influences managerial performance and innovativeness. Strateg. Manag. J. 2004, 25, 541-562. [CrossRef] 
54. Huang, Y.-F.; Chen, C.-J. The impact of technological diversity and organizational slack on innovation. Technovation 2010, 30, 420-428. [CrossRef]

55. Lin, C.; Chang, C.-C. The effect of technological diversification on organizational performance: An empirical study of S\&P 500 manufacturing firms. Technol. Forecast. Soc. Chang. 2015, 90, 575-586. [CrossRef]

56. Subramaniam, M.; Youndt, M.A. The Influence of Intellectual Capital on the Types of Innovative Capabilities. Acad. Manag. J. 2005, 48, 450-463. [CrossRef]

57. Perkmann, M.; Tartari, V.; McKelvey, M.; Autio, E.; Broström, A.; D’Este, P.; Fini, R.; Geuna, A.; Grimaldi, R.; Hughes, A.; et al. Academic engagement and commercialisation: A review of the literature on university-industry relations. Res. Policy 2013, 42 , 423-442. [CrossRef]

58. Van de Vrande, V. Balancing your technology-sourcing portfolio: How sourcing mode diversity enhances innovative performance. Strateg. Manag. J. 2013, 34, 610-621. [CrossRef]

59. Oerlemans, L.; Knoben, J.; Pretorius, M. Alliance portfolio diversity, radical and incremental innovation: The moderating role of technology management. Technovation 2013, 33, 234-246. [CrossRef]

60. Nonaka, I. A Dynamic Theory of Organizational Knowledge Creation. Organ. Sci. 1994, 5, 14-37. [CrossRef]

61. Tortoriello, M.; Reagans, R.; McEvily, B. Bridging the Knowledge Gap: The Influence of Strong Ties, Network Cohesion, and Network Range on the Transfer of Knowledge Between Organizational Units. Organ. Sci. 2012, 23, 1024-1039. [CrossRef]

62. Ryu, C.; Yong, J.K.; Chaudhury, A.; Rao, H.R. Knowledge acquisition via three learning processes in enterprise information portals: Learning-by-investment, learning-by-doing, and learning-from-others. Mis Q. 2005, 29, 245-278. [CrossRef]

63. Arikan, A.T.; Arıkan, A.T. Interfirm Knowledge Exchanges and the Knowledge Creation Capability of Clusters. Acad. Manag. Rev. 2009, 34, 658-676. [CrossRef]

64. Gorman, M.E. Types of Knowledge and Their Roles in Technology Transfer. J. Technol. Transf. 2002, 27, 219-231. [CrossRef]

65. Karnani, F. The university's unknown knowledge: Tacit knowledge, technology transfer and university spin-offs findings from an empirical study based on the theory of knowledge. J. Technol. Transf. 2013, 38, 235-250. [CrossRef]

66. Oliver, C. Determinants of Interorganizational Relationships: Integration and Future Directions. Acad. Manag. Rev. 1990, 15, 241-265. [CrossRef]

67. Perkmann, M.; King, Z.; Pavelin, S. Engaging excellence? Effects of faculty quality on university engagement with industry. Res. Policy 2011, 40, 539-552. [CrossRef]

68. Okamuro, H. Determinants of successful R\&D cooperation in Japanese small businesses: The impact of organizational and contractual characteristics. Res. Policy 2007, 36, 1529-1544. [CrossRef]

69. Laursen, K.; Salter, A. Searching high and low: What types of firms use universities as a source of innovation? Res. Policy 2004, 33, 1201-1215. [CrossRef]

70. Lee, J.; Win, H. Technology transfer between university research centers and industry in Singapore. Technovation 2004, 24, 433-442. [CrossRef]

71. Kim, B. Managing the transition of technology life cycle. Technovation 2003, 23, 371-381. [CrossRef]

72. Inkpen, A.C. Learning Through Joint Ventures: A Framework Of Knowledge Acquisition. J. Manag. Stud. 2000, 37, 1019-1044. [CrossRef]

73. Darr, E.D.; Argote, L.; Epple, D. The Acquisition, Transfer, and Depreciation of Knowledge in Service Organizations: Productivity in Franchises. Manag. Sci. 1995, 41, 1750-1762. [CrossRef]

74. Zander, U.; Kogut, B. Knowledge and the Speed of the Transfer and Imitation of Organizational Capabilities: An Empirical Test. Organ. Sci. 1995, 6, 76-92. [CrossRef]

75. Hansen, M.T. The Search-Transfer Problem: The Role of Weak Ties in Sharing Knowledge across Organization Subunits. Adm. Sci. Q. 1999, 44, 82-111. [CrossRef]

76. Yli-Renko, H.; Autio, E.; Sapienza, H.J. Social capital, knowledge acquisition, and knowledge exploitation in young technologybased firms. Strateg. Manag. J. 2001, 22, 587-613. [CrossRef]

77. Szulanski, G. Exploring internal stickiness: Impediments to the transfer of best practice within the firm. Strateg. Manag. J. 1996, 17, 27-43. [CrossRef]

78. Fang, S.-R.; Fang, S.-C.; Chou, C.-H.; Yang, S.-M.; Tsai, F.-S. Relationship learning and innovation: The role of relationship-specific memory. Ind. Mark. Manag. 2011, 40, 743-753. [CrossRef]

79. Wehner, M.C.; Schwens, C.; Kabst, R. Individual-level experience and organizational-level absorptive capacity: The special case of international new ventures. J. Bus. Econ. 2015, 85, 545-568. [CrossRef]

80. Kostopoulos, K.; Papalexandris, A.; Papachroni, M.; Ioannou, G. Absorptive capacity, innovation, and financial performance. J. Bus. Res. 2011, 64, 1335-1343. [CrossRef]

81. Podsakoff, P.M.; MacKenzie, S.B.; Lee, J.Y.; Podsakoff, N.P. Common method biases in behavioral research: A critical review of the literature and recommended remedies. J. Appl. Psychol. 2003, 88, 879-903. [CrossRef]

82. Pérez-Luño, A.; Cabello-Medina, C.; Lavado, A.C.; Rodríguez, G.C. How social capital and knowledge affect innovation. J. Bus. Res. 2011, 64, 1369-1376. [CrossRef]

83. James, L.R. Aggregation bias in estimates of perceptual agreement. J. Appl. Psychol. 1982, 67, 219-229. [CrossRef]

84. Mehreen, H.; Rammal, H.G.; Pereira, V.; Del Giudice, M. Investigating the influence of absorptive capacity of recipients within cross-border transfer of knowledge: Evidence from emerging markets. Int. Mark. Rev. 2021, ahead of print. [CrossRef] 
85. Un, C.A.; Asakawa, K. Types of R\&D Collaborations and Process Innovation: The Benefit of Collaborating Upstream in the Knowledge Chain. J. Prod. Innov. Manag. 2014, 32, 138-153. [CrossRef]

86. Lhuillery, S.; Pfister, E. R\&D cooperation and failures in innovation projects: Empirical evidence from French CIS data. Res. Policy 2009, 38, 45-57. [CrossRef]

87. Todo, Y.; Matous, P.; Inoue, H. The strength of long ties and the weakness of strong ties: Knowledge diffusion through supply chain networks. Res. Policy 2016, 45, 1890-1906. [CrossRef]

88. Wang, Q.; Zhao, L.; Chang-Richards, A.; Zhang, Y.; Li, H. Understanding the Impact of Social Capital on the Innovation Performance of Construction Enterprises: Based on the Mediating Effect of Knowledge Transfer. Sustainability 2021, 13, 5099. [CrossRef]

89. Cao, X.; Xing, Z.; Sun, K. Collaboration network, technology network and technological development: A patent analysis in the Chinese green technological field of energy saving. Foresight 2021, 23, 33-49. [CrossRef]

90. Nambisan, S. Industry technical committees, technological distance, and innovation performance. Res. Policy 2013, 42, 928-940. [CrossRef]

91. Quintana-García, C.; Velasco, C.; Ángel, B. Innovative competence, exploration and exploitation: The influence of technological diversification. Res. Policy 2008, 37, 492-507. [CrossRef]

92. Schulze, A.; Brojerdi, G.J.C. The Effect of the Distance between Partners' Knowledge Components on Collaborative Innovation. Eur. Manag. Rev. 2012, 9, 85-98. [CrossRef]

93. Belderbos, R.; Cassiman, B.; Faems, D.; Leten, B.; Van Looy, B. Co-ownership of intellectual property: Exploring the valueappropriation and value-creation implications of co-patenting with different partners. Res. Policy 2014, 43, 841-852. [CrossRef]

94. Wu, Y.; Gu, F.; Ji, Y.; Guo, J.; Fan, Y. Technological capability, eco-innovation performance, and cooperative R\&D strategy in new energy vehicle industry: Evidence from listed companies in China. J. Clean. Prod. 2020, 261, 121157. [CrossRef]

95. Van Beers, C.; Zand, F. R\&D Cooperation, Partner Diversity, and Innovation Performance: An Empirical Analysis. J. Prod. Innov. Manag. 2013, 31, 292-312. [CrossRef]

96. Barge-Gil, A. Cooperation-based innovators and peripheral cooperators: An empirical analysis of their characteristics and behavior. Technovation 2010, 30, 195-206. [CrossRef]

97. Zhou, K.Z.; Gao, G.Y.; Zhao, H. State Ownership and Firm Innovation in China: An Integrated View of Institutional and Efficiency Logics. Adm. Sci. Q. 2016, 62, 375-404. [CrossRef]

98. Huang, K.G.-L.; Geng, X.; Wang, H. Institutional Regime Shift in Intellectual Property Rights and Innovation Strategies of Firms in China. Organ. Sci. 2017, 28, 355-377. [CrossRef]

99. Walter, J.; Lechner, C.; Kellermanns, F.W. Knowledge transfer between and within alliance partners: Private versus collective benefits of social capital. J. Bus. Res. 2007, 60, 698-710. [CrossRef]

100. Xu, D.; Lu, J.W.; Gu, Q. Organizational Forms and Multi-population Dynamics: Economic Transition in China. Adm. Sci. Q. 2014, 59, 517-547. [CrossRef] 